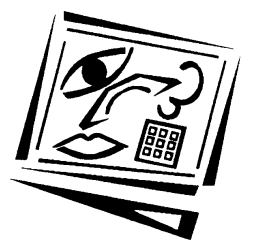

\title{
Hypermedia and discovery based learning: What value?
}

\author{
Gabriel Jacobs \\ University of Wales Swansea, UK
}

\begin{abstract}
In 1992, I published a paper entitled 'Hypermedia and discovery based learning: A historical perspective'. It traced the swings in the history of educational thinking between, on the one hand, support for conventional curriculum based learning and, on the other, the non-linear approach expressed by many educational commentators over the centuries. As I saw things, hyperlink technology would finally allow learning truly to mesh with the free association characteristics of the human mind. Once the technology had matured, it would be a teaching resource that would transform passive learners into active thinkers. Thirteen years on, I take a critical look at those optimistic conclusions. Are students better equipped to learn than previously? Are they able to think reflectively to a greater degree than their counterparts of a decade or two ago? This present paper addresses such questions, the result being that the guarded optimism of 1992 has turned to a deep pessimism.
\end{abstract}

\section{Introduction}

It will be appropriate to state at the outset of this paper that the opinions expressed in its conclusions are likely to be viewed as controversial. Most publications on learning technology start from the assumption that it is a Good Thing, the order of the day being the encouragement of new learning paradigms which involve active enquiry, and that good teachers are facilitators, not mere providers of knowledge. Theoretical discussions are generally concerned with constructing models to exploit the potential benefits of technology enabled learning; only very rarely is its overall value seriously questioned. Trials and experiments by and large present positive results even if accompanied by caveats. Yet a certain bias must surely be acknowledged. Professional learning technologists, decision makers involved in promoting computer assisted education, and teachers who use learning technology at the coal face, have in many cases invested significant amounts of time and energy in setting up and running technology enabled learning systems; it would be surprising if they were in 
the main to argue that their investment had failed to produce an acceptable return.

The notion that the future of education lies firmly in learning technology, seen as a tool of undoubted magnitude and a powerful remedy for many educational ills, has penetrated deeply into the psyche not only of those involved in delivery but also of observers, including those in power within national governments. The UK offers a prime example. The Dearing Report of eight years ago (Dearing, 1997), commissioned by the UK Government with the aim of setting the agenda for higher education in Britain over the next 25 years, concentrated heavily on the gains, at both institutional and individual levels, to be had by the use of learning technology, and in particular by the exploitation of the Internet. Nowhere in that long report was there even a hint that moving in the direction of such technology could be anything other than advantageous. Several other governmental reports followed suit, and sizeable funds have since been made available for the implementation of technology enabled learning systems.

As a result, in British schools, as in schools elsewhere, the use of virtual learning environments is spreading rapidly, while in most universities they have already become almost a sine qua non of teaching programs. We are bombarded by the encouragements of eminent thinkers to rid ourselves of the constraints of conventional teaching, to see the flaws in the traditional academic ethos, to accept the value of new educational concepts, to adopt a holistic, discovery based approach to learning as opposed to the age old process of rote learning. That process, according to one distinguished British commentator on educational matters, has resulted in the UK always having been "a clever nation but woefully incompetent". In his opinion, the situation can be remedied only by a strengthening of the existing change of direction away from the acquisition of second hand knowledge towards a knowledge acquired by discovery and experience, since with the advent of the Internet, "nobody now needs to remember information but only where to find it". In short, "problem based activity is now the learning tool of the future" (Hills, 2004:23-24).

It is, in good measure, the notion of the hyperlink which has led to such a standpoint, a notion which - it hardly needs to be repeated - makes the world wide web what it is, an unimaginably intricate labyrinth of interconnected nodes whose very makeup invites investigation and discovery. Vannevar Bush is rightly celebrated for his theoretical brainchild the Memex machine (Bush, 1945), and Ted Nelson (Keep, McLaughlin \& Parmer, 2000a), and Douglas Engelbart (Keep, McLaughlin \& Parmer, $2000 \mathrm{~b}$ ) for their groundbreaking ideas with respect to hypertext, although it should be added that the implementation of hyperlinks would in any event undoubtedly have become self evident with the rise of computer networks. 
Moreover, the concept of links to be explored has existed almost since the invention of written communication. Only the clumsy configuration of physically written material, relying for its connections on references to other physically written material, has until our own era prevented the concept from achieving its potential, that of allowing pathways instantly to be investigated and thus, it is thought by many, for real learning to be achieved by active enquiry.

Likewise, the view that learning by discovery is superior to rote learning is hardly new, as I demonstrated in the early 1990s in a paper which traced the history of the swings of the educational pendulum between endorsement of formal, step by step instruction, and support for learning being best accomplished by individual exploration (Jacobs, 1992).

\section{A succinct history of discovery based learning}

The aim of that paper was, then, to show that thinkers throughout the ages have punctuated the annals of educational theory with the conviction that learning should be closely allied to finding out, in preference to simply being informed. To that end, it dealt with a number of significant landmarks, beginning with the ancient Greeks. Socrates describes a lesson given to an uneducated slave in which the latter is apparently made to discover for himself the validity of a rule of geometry (Plato, 1985:82-86). In the fourth century AD, St Augustine asserted that the true art of teaching was to stimulate a learner's curiosity (Oates, 1947). During the Renaissance, Erasmus contended that the most effective teachers are facilitators, not dictators (Woodworth, 1904), while Juan Luís Vives (Watson, 1913) and Michel de Montaigne (Montaigne, 1965) argued strongly for learning by individual exploration.

In the seventeenth century, Comenius laid great emphasis on the precept that learners must arrive at the truth by following paths of their own choosing (Monore, 1900), and both Locke (Locke, 1894) and Barclay (Barclay, 1743) admonished teachers who did nothing more than dispense knowledge. From the eighteenth to the early twentieth century, Rousseau, Kant, Wordsworth, Pestalozzi, Spencer, Dewey, Montessori, Whitehead, all made a strong case for discovery based learning (respectively: Rousseau, 1955; Curton, 1899; Wordsworth, 1857:186; Guimps, 1890; Spencer, 1911; Dewey, 1938; Montessori, 1912; Whitehead, 1929). All saw their ideas ignored, rejected or actively disallowed by their respective establishments. Rousseau's treatise on education, Émile, for example, in which he set out the first unified, child centred philosophy of learning (Rousseau, 1955), eventually led to the burning of the book and the issuing of a warrant for its author's arrest. The Mussolini government outlawed all Montessorian schemes in Fascist Italy (Montessori, 2005). 
In the second half of the twentieth century, as the idea of the teaching machine began to turn into a reality, the argument centred around the proposals of B.F. Skinner (Skinner, 1968) and his advocates, such as Gagné (Gagné, 1975) and Rowntree (Rowntree, 1982), and those of Jerome Bruner (Bruner, 1966) and his supporters, such as Papert (Papert, 1980). Skinner argued for the virtues of programmed instruction. Bruner questioned the value of pre-determined educational pathways, and argued for the nonsequential form of enquiry advocated by Vygotsky, who is often cited as the primary source of contemporary ideas relating to discovery based learning (Vygotsky, 1962).

Following the historical survey, my paper concluded with the contention that while each age has had the arrogance to believe that it has been the first to promote discovery based learning, the advent of hypermedia technology meant that a sea change was in the offing: we were, I believed, on the verge of a genuine educational revolution which could not do otherwise than to lead to better ways of learning. And, indeed, Bruner and his ilk appear generally to have won the day. There was a blip in the early 1990s when the pendulum began to swing the other way. In the UK, for example, we witnessed the Back to Basics campaign under the then Prime Minister John Major, a policy intended to improve literacy and numeracy among school children and a reaction against left wing educational strategies in which teachers had been trained to have their students find things out for themselves rather than merely to feed them information. "The progressive theorists have had their say," exclaimed Major, "and they've had their day." (Major, 1991). The initiative was a failure, notably because of the strength of feeling among educational analysts with respect to the gains to be had from the supposedly new ways of learning and teaching, bolstered by the fact that the launch of the campaign coincided with the rise of computer networking.

Since then, the Internet, with its intrinsic emulation of the free association characteristics of the human mind, has become the overriding influence on educational wisdom. Over the last decade or so, it has led to a way of teaching and learning of which the likes of Pestalozzi, Rousseau and Dewey would have whole heartedly approved. It seems probable that even with the future backlashes which history teaches us will be inevitable, the paradigm represented by the world wide web will be an unstoppable educational force. In the light of this, it is pertinent to question the effect it has had. I was without doubt justified in concluding in my 1992 paper that the concept of hypermedia - a concept which I saw as "the best hope yet for a general acceptance of discovery based learning after millennia of rejection" (Jacobs, 1992:120) - would bring about, for the first time, a pervasive educational revolution. But was I also justified in maintaining that once the technology had become sufficiently robust, as it has now 
become, the effect would be to create a generation of students able to think reflectively, students whose first instinct would be to doubt before accepting off the peg ideas, to explore freely with the result that curiosity would be stimulated to the point of achieving full conceptual understanding?

\section{What progress?}

The answer to that question unfortunately has to be a barely qualified No.

There is a vast theoretical research literature on discovery based learning and allied educational methodologies: experiential learning, incidental learning, active learning, instance based learning, enquiry based learning (if they are all not identical names for the same thing) and so forth. There have been innumerable trials, often comparing cohorts of students taught by contrasting methods, and with the resulting published papers containing long lists of references which give them an air of authority. There exist throughout the world numerous organisations devoted to the principles of discovery based and experiential learning. Yet despite all the enthusiasm and excitement, the results appear to be disappointing.

As I mentioned in the introduction to this paper, published reports of failure in trials are few and far between, although there has been a fair amount of research on the pitfalls of discovery based learning programs delivered via the Internet. Weaver (2002), for example, lists a number of such pitfalls including overestimating results, over reliance on technology, and "believing that if you build it, they will come." This latter point has a resonance which goes beyond the Skinnerian idea that the use of technology itself is sufficient to retain a learner's interest. Skinner confidently wrote of his teaching machine that "the mere manipulation of the device will probably be reinforcing enough to keep the average pupil at work for a suitable period each day." (Skinner, 1968:24). On the whole, as general experience has shown, this has not turned out to be the case, even with today's machines which are immensely more powerful than Skinner's primitive apparatus. But it is not only a question of the appeal or otherwise of technology; it is also a question of general motivation. The feeling of many, perhaps most, teachers is that what young students crave is not to explore but rather to be receptacles of information. Schoolchildren and university students alike want, above all, handouts of lecture notes and ideas ultra-condensed in PowerPoint slide bullet points which can be learned by heart ready for regurgitation, all too often only half digested. It may be unfair to blame them when their future prospects depend heavily on the results of examinations which still tend to test retention of information rather than critical faculties, but it has to be added, regardless, that without a solid foundation of received knowledge there will be little 
chance of genuinely valuable learning to be had from self guided enquiry. Added to which is the fact that when students are left to their own devices, they do not always choose the best pathways for learning, a situation gravely exacerbated by the sheer amount of misinformation and unsupported opinions, not to say junk, to be found everywhere on the Internet. We are still at a stage at which, with few exceptions, the young (and many of their elders) tend automatically to accept ideas if they appear in a printed font.

Some direct evidence for the failure of so called innovative pedagogical programs is inferred in the largest global educational survey available, the one conducted regularly by the OECD's Programme for International Student Assessment (PISA). The 2003 report (PISA, 2003) offers an exhaustive comparison between the academic attainments of 15 year olds in 49 countries (representing almost a third of the world's population). Space does not allow here a discussion of the many fascinating details it contains, but in the context of discovery based learning it is worth focusing on one section of it.

Increased proficiency in solving problems, that is, in applying theoretical knowledge, is one of the principal claimed advantages of learning by discovery. The PISA 2003 report contains a statistical comparison, country by country, of the relationship between performance in mathematics (the theory) and performance in problem solving (the application of the theory) (PISA, 2003:36). It is to be noted that students performed significantly worse in solving problems than in mathematics (differing by at least 10 percentage points) in two of the three OECD countries - Iceland and the Netherlands - where discovery-based learning has been heavily promoted. On the other hand, in all three of the OECD countries where students performed significantly higher in solving problems than in mathematics Germany, Hungary and Japan - discovery based learning has taken less of a foothold.

What is more, while the UK has solidly promoted a policy of discovery based learning in schools for the last few years, the 2004 PISA report, which at the time of writing (August 2005) is not yet published, is said to show that the country has slipped down the league table in mathematics from 8th place in 2001 to 18th place, in science from 4th to 11th, and in general comprehension from 7th to 11th (Clare, 2004). Notable also in this context is that in Finland, which tops the 2004 list of OECD countries, one is more likely to find a classroom lined with stuffed birds in glass cases than with computers. One must, of course, treat statistics such as these with a measure of circumspection: myriad factors influence learning and understanding. But it would be foolish to ignore what may at least be a trend, and one which should perhaps send us back to basics. 


\section{Where to from here?}

An opposing view is that we have simply not gone far enough, that the current generally used mixed mode of educational delivery - a balance between exploratory learning and the straight transfer of knowledge - is too milk and water a philosophy to succeed. In other words, we might do well fully to heed the exhortations of Roger Schank, the most outspoken modern exponent of discovery based learning, by implementing educational schemes which rely not at all on traditional one way instruction. Schank contends that "[I]n the school system, learning is basically done by students sitting and the teacher talking. Well, 'you sit and I talk' is not the way people learn" (Schank, 1997: 12). He would therefore abolish classrooms altogether (Schank \& Kemi, 2000: 5).

Dare we take the risk of pursuing the Schank line? Dare we gamble all by trusting what have become the platitudes expressed by educational visionaries - learning is something you do, not something you watch; information is not instruction; telling is not teaching; learning is active not passive? Can we trust the often cited alleged facts about memory retention, statistics which tell us, for instance, that we remember $10 \%$ of what we read, $20 \%$ of what we hear, $30 \%$ of what we see, $70 \%$ of what we see and hear, and $90 \%$ of what we see and hear when we have discovered something for ourselves? Who has the indisputable evidence for such claims? Caution may well be the better part of valour, and it is indeed such caution which has throughout the ages prevented discovery based learning from becoming the norm.

There is also a potent positive reason for not following Schanks' lead. One school of thought takes as its basis the notion of Skinnerian programmed learning without slavishly adhering to its principles. It has been well characterised in a report on mathematics education in the UK (LMS, 1995) commissioned by the London Mathematical Society. The report roundly condemned the shift of emphasis in teaching mathematics in UK schools, a shift away from basic tools towards projects and investigations, noting that "inappropriate insistence on working within a context ... can often obscure the underlying mathematics", and that official advice to teachers that processes are as important as techniques fails to take into account that "to gain a genuine understanding of any process, it is necessary first to achieve a robust technical fluency" (LMS, 1995: 9). The point, emphasised in a more recent report (Manchester 2005: 6, 10,13), is that in mathematics as in many other subject areas, it may often be necessary to forego the idea that one should never teach a topic which will not be fully understood by learners. Within many disciplines, it is worthwhile teaching some techniques, even if learners are not sufficiently advanced to appreciate their significance. Once such techniques have become second nature, so that little or no prior 
conscious thought is required to apply them, they can be used for exploring unfamiliar concepts. If, on the other hand, certain basic but difficult procedures are held back until such time that learners are deemed able fully to grasp how they work, it may well be too late for good use of them ever to be made. The view expressed in the LMS report went so much against the educational trend of the mid-1990s that one suspects its writers of being very much tongue in cheek when they stated, clearly targeting the Bruner school of thought, that harder subjects must sometimes precede easier ones, "despite recent advances in cognitive psychology" (LMS, 1995:10).

There is, of course, no fundamental reason why a curriculum based approach should preclude the use of hypermedia for individual exploration, nor why it should lead inexorably to drill oriented procedures, parrot fashion learning by rote, and the suppression of curiosity. Indeed, a number of contemporary observers have concluded that mixed mode delivery provides the perfect half way house, one that recognises the inevitability of the use of hypermedia technology, and fully takes on board its undoubted value, without rejecting the long established, one way, master-apprentice relationship in which the teacher talks and the student listens. The approach here, then, is that of teacher controlled exploratory contexts. Bransford, Brown \& Cocking (1999), in their chapter devoted to technology supported learning (Chapter 9, 194-218), provide an excellent detailed synthesis of the differing views with respect to the use of computers in education, and although the report is now six years old, the principles it examines remain for the most part unchanged. The general stance is precisely that of encouragement to explore, but under the guidance of a teacher who, at each stage of progression, presents the essential tenets. As Bransford et al state in their conclusion:

The key attribute of expertise is a detailed and organized understanding of the important facts within a specific domain. Education needs to provide children with sufficient mastery of the details of particular subject matters so that they have a foundation for further exploration within those domains. (227)

However, the numerous case studies and examples found in the Bransford report are without exception ones which recount the success of discovery based learning projects (and, typically, students making very impressive gains in understanding after engaging in them), with no mention of any possible parti pris, or criticism of methodology or reliability of results. Despite a great deal of common sense, and the caveat insisted upon that if students are left to their own devices they are unlikely to spend time efficiently (165), Bransford et al take it for granted that learning by discovery, and the Internet based hypermedia which facilitates it, are beyond any hint of disapproval. But as Laurillard points out in the most 
cited and most influential work on higher education teaching strategies, Rethinking university teaching (Laurillard, 2002:63), there is no dependable research evidence to prove that any given teaching tactic is the right one. As she puts it, "we are basing the design of teaching strategy on a minimal analysis of student learning", and adds:

\footnotetext{
We cannot claim to have sorted out once and for all what students need to be told if they are to make proper sense of topic X. No matter how much detailed research is done on the way the topic is conceptualised, the solution will not necessarily be found for new ways of putting it across. The new way of telling may sort out one difficulty, but it may well create others (Laurillard, 2002: 71).
}

I would go further. Being uncertain about the best tactic does not automatically necessitate rethinking, or at least not a complete rethink, Hypermedia is a relentless force. It is one which has penetrated our consciousness in much the same way as word processing has made the concept of Cut and Paste ubiquitous. While it is commonplace in the research literature to state that technology does not guarantee effective learning, it is nevertheless often taken as read that the use of hypermedia by students can only enhance the learning experience. I would say that it can do considerable harm. Not, of course, in itself, but in the way it is seen as a must-have, to the detriment of traditional tools. Constructivist epistemology calls for a multiplicity of perspectives such that learners have a range of options from which to construct their own knowledge. But many basic techniques and skills, and much knowledge, whether or not deeply understood by students, can be effectively taught only by explanation, not by promoting free exploration; otherwise one is building on sand.

It is all very well having as one's goal as an educator the freeing of the human mind to pursue its creative capacities, but such freedom does not come free: it comes at the cost of inadequacy if over emphasised, and, in particular, if offered too early. Mozart, for all his creative genius, did not discover via Brunerian guesswork how to play the piano; he had first to remember the standard fingerings taught to him by his father, even if, at the age of three, he did not fully apprehend the need for them. Within the problematical interplay of technological change and educational values, a predicament which is qualitatively different from previous areas of disquiet in the history of education, and with which all educators are now obliged to grapple, any application of the time honoured method of remembering before discovering will for my part be welcomed.

I began my brief outline of the history of discovery based learning, above (and as in my original 1992 paper), with Socrates, whose Meno is sometimes cited as containing the first recorded instance of teaching not by explanation but by gently allowing a student to re-discover a principle. 
Laurillard (2002:74-77), under the heading The Myth of Socratic Teaching, takes up the gauntlet, arguing that Socrates, while appearing to tease out concepts, actually "engages in a kind of rhetorical bullying" (74) by reducing Meno's slave to helplessness. For Laurillard, this is nothing short of authoritarianism, thus the antithesis of facilitation and scaffolding. I agree, but I would not hold that this is of necessity something to be avoided. On the contrary, without such authoritarianism one often ends up with a mixed bag of disconnected, or only vaguely connected ideas, and with complaints by so many teachers, especially at university level, about the apparent ignorance of their students.

The aim of educating students such that they can transfer learning to unfamiliar problems and situations is not, in my view, achieved by giving them their reins before they have learned to walk safely. Hypermedia technology, for all its great potential, a potential undreamed of in previous eras, is a dangerous weapon in the hands of the inexpert. Nobody has put this idea more compellingly than Tom Reeves, Professor of Instructional Technology in the University of Georgia, USA, to whom I leave the last word:

Although there are many advocates of discovery-based environments for the learning of social studies, science, and even mathematics in schools, most of these people would probably prefer their brain surgeons to be trained via direct instruction. (Reeves, 1995)

\section{References}

Barclay, J. (1743). A treatise on education. Edinburgh, UK: Cochran.

Bransford, J.D., Brown, A.L. \& Cocking, R.R. (Eds) (1999). How people learn: Brain, mind, experience, and school. Washington DC: National Academy Press. http: / / www.nap.edu/openbook/0309065577/ html/index.html

Bruner, J.S. (1966). Toward a theory of instruction. Boston MA: Belknap Press (Harvard University Press).

Bush, V. (1945). As we may think. The Atlantic Monthly, 176(1), 101-108. http: / / www.theatlantic.com/doc/194507/bush

Clare, J. (2004). UK slips in the world education league. Daily Telegraph (London), 7 December (summary statistics of the 2004 OECD PISA report). [verified 28 Aug 2005] http:/ / www.telegraph.co.uk/news/main.jhtml?xml=/news/2004/12/07/nscho07.xml

Curton, A. (1899). Kant on education: A translation of the Pädagogic. London: Kegan Paul.

Dearing, R. et al (1997). Higher education in the learning society: Report of the National Committee of Inquiry into Higher Education. London: The Stationery Office. http: / / www.leeds.ac.uk/educol/ncihe/ 
Dewey, J. (1938). Experience and education. London: Macmillan.

Gagné, R.M. (1975). The essentials of learning for instruction. Hinsdale IL: Dryden.

Guimps, R. de (1890). Pestalozzi: His life and work. Trans. J. Russell. New York: Appleton.

Hills, G. (2004). In from the cold - the rise of vocational education. Journal of the Royal Society of Arts, November, 22-25.

Jacobs, G. (1992). Hypermedia and discovery-based learning: A historical perspective. British Journal of Educational Technology, 23(2), 113-121.

Keep, C., McLaughlin, T. \& Parmer, R. (2000a). Ted Nelson and Xanadu. http: / / www.iath.virginia.edu/elab/hfl0155.html

Keep, C., McLaughlin, T. \& Parmer, R. (2000b). Douglas Engelbart. http: / / www.iath.virginia.edu/elab/hfl0035.html

Laurillard, D. (2002). Rethinking university teaching. 2nd edition. London and New York: Routledge.

LMS (1995). Tackling the mathematics problem. London: The Mathematical Society. http:/ / www.lms.ac.uk/ policy/tackling/ report.html

Locke, J. (1894). An essay concerning human understanding (F. Fraser, Ed). Oxford: Clarendon Press.

Major, J. (1991). Conservative Party Conference Speech 1991. http:/ / www.johnmajor.co.uk/1991.htm [viewed 30 Feb 2005; verified 28 Aug 2005]

Manchester (2005). Where will the next generation of UK mathematicians come from? (Preliminary report of a meeting held in Manchester, 18-19 March 2005). Manchester, UK: Manchester Institute of Mathematical Sciences. [verified 28 Aug 2005] http:/ / www.ma.umist.ac.uk/avb/pdf/WhereFromPreliminaryReport.pdf

Monore, W.S. (1900). Comenius and the beginnings of educational reform. London: Heinemann.

Montaigne, M. de. (1965). On the instruction of children. In Complete essays (Trans. D.M. Frame). Stanford CA: Stanford University Press.

Montessori, M. (1912). Montessori method. (Trans. A. George) London: Heinemann.

Montessori (2005). About Montessori. http: / / www.ourmontessori.com/about_montessori.html

Oates, W.J. (1947). Basic Writings of St. Augustine (vol. 1). New York: Random.

Papert, S. (1980). Mindstorms: Children, computers and powerful ideas. New York: Basic Books.

PISA (2003). Learning for tomorrow's world: First results from PISA 2003. Paris: Organisation for Economic Co-operation and Development (OECD).

Plato (1985). Meno. (Trans.A.W. Sharples). Warminster, UK: Aris and Phillips. 
Reeves, T. (1995). Evaluating what really matters in computer-based education. http: / / www.educationau.edu.au/archives / cp/ reeves.htm

Rousseau, J-J. (1955). Emile. (Trans. B. Foxley). London: Dent.

Rowntree, D. (1982). Educational technology in the curriculum development. London: Butler and Tanner.

Schank, R.C. (1997). Virtual learning: A revolutionary approach to building a highly skilled workplace. New York: McGraw-Hill.

Schank, R.C. and Kemi, J. (2000). Extracurriculars as the curriculum: A vision of education for the 21st century. White Paper presented to the US Department of Education. Chicago: Northwestern University and Cognitive Arts Corporation. [verified 28 Aug 2005] http:/ / www.air.org/forum/abschank.htm

Skinner, B.F. (1968). The technology of teaching. New York: Meredith.

Spencer, H. (1911). Education: Intellectual, moral and physical. London: Williams and Norgate.

Vygotsky, L.S. (1962). Thought and language. (Trans E. Hanfmann \& G. Vakar). Boston MA: MIT Press.

Watson, F. (1913). Vives on education. Cambridge University Press.

Weaver, P. (2002). Preventing e-learning failure: Ten common pitfalls and how to avoid them. Training $\mathcal{E}$ Development, 56(8), 45-50.

Whitehead, A.N. (1929). The aims of education. London: Williams \& Norgate.

Woodworth, W.H. (1904). Desiderius Erasmus: Concerning the aim and method of education. Cambridge University Press.

Worsdworth, G.C. (1857). Memoirs of William Wordsworth (vol. 2). London: Edward Moxon.

Professor Gabriel Jacobs, School of Business and Economics, University of Wales Swansea, Singleton Park, Swansea SA2 8PP, Wales, UK. Email: g.c.jacobs@swan.ac.uk Web: http: / / www.swan.ac.uk/ebms / 